\title{
Supplementary File 1.
}

PRISMA-P (Preferred Reporting Items for Systematic review and Meta-Analysis Protocols) 2015 checklist: recommended items to address in a systematic review protocol*

\begin{tabular}{|c|c|c|c|}
\hline Section and topic & $\begin{array}{c}\text { Item } \\
\text { No }\end{array}$ & Checklist item & $\begin{array}{l}\text { Information } \\
\text { Reported }\end{array}$ \\
\hline \multicolumn{4}{|c|}{ ADMINISTRATIVE INFORMATION } \\
\hline \multicolumn{4}{|l|}{ Title: } \\
\hline Identification & 1a & Identify the report as a protocol of a systematic review & $\mathrm{X}$ \\
\hline Update & $1 \mathrm{~b}$ & If the protocol is for an update of a previous systematic review, identify as such & NA \\
\hline Registration & 2 & If registered, provide the name of the registry (such as PROSPERO) and registration number & $\mathrm{X}$ \\
\hline \multicolumn{4}{|l|}{ Authors: } \\
\hline Contact & $3 \mathrm{a}$ & $\begin{array}{l}\text { Provide name, institutional affiliation, e-mail address of all protocol authors; provide physical mailing address of } \\
\text { corresponding author }\end{array}$ & $\mathrm{X}$ \\
\hline Contributions & $3 \mathrm{~b}$ & Describe contributions of protocol authors and identify the guarantor of the review & \\
\hline Amendments & 4 & $\begin{array}{l}\text { If the protocol represents an amendment of a previously completed or published protocol, identify as such and list changes; } \\
\text { otherwise, state plan for documenting important protocol amendments }\end{array}$ & NA \\
\hline \multicolumn{4}{|l|}{ Support: } \\
\hline Sources & $5 \mathrm{a}$ & Indicate sources of financial or other support for the review & $\mathrm{X}$ \\
\hline Sponsor & $5 b$ & Provide name for the review funder and/or sponsor & NA \\
\hline $\begin{array}{l}\text { Role of sponsor } \\
\text { or funder }\end{array}$ & $5 \mathrm{c}$ & Describe roles of funder(s), sponsor(s), and/or institution(s), if any, in developing the protocol & NA \\
\hline \multicolumn{4}{|l|}{ INTRODUCTION } \\
\hline Rationale & 6 & Describe the rationale for the review in the context of what is already known & $\mathrm{X}$ \\
\hline Objectives & 7 & $\begin{array}{l}\text { Provide an explicit statement of the question(s) the review will address with reference to participants, interventions, } \\
\text { comparators, and outcomes (PICO) }\end{array}$ & $\mathrm{X}$ \\
\hline \multicolumn{4}{|l|}{ METHODS } \\
\hline Eligibility criteria & 8 & $\begin{array}{l}\text { Specify the study characteristics (such as PICO, study design, setting, time frame) and report characteristics (such as years } \\
\text { considered, language, publication status) to be used as criteria for eligibility for the review }\end{array}$ & $\mathrm{X}$ \\
\hline Information sources & 9 & $\begin{array}{l}\text { Describe all intended information sources (such as electronic databases, contact with study authors, trial registers or other grey } \\
\text { literature sources) with planned dates of coverage }\end{array}$ & $\mathrm{X}$ \\
\hline
\end{tabular}




\begin{tabular}{|c|c|c|c|}
\hline Search strategy & 10 & $\begin{array}{l}\text { Present draft of search strategy to be used for at least one electronic database, including planned limits, such that it could be } \\
\text { repeated }\end{array}$ & $\mathrm{X}$ \\
\hline \multicolumn{4}{|l|}{ Study records: } \\
\hline $\begin{array}{l}\text { Data } \\
\text { management }\end{array}$ & $11 \mathrm{a}$ & Describe the mechanism(s) that will be used to manage records and data throughout the review & $\mathrm{X}$ \\
\hline $\begin{array}{l}\text { Selection } \\
\text { process }\end{array}$ & $11 \mathrm{~b}$ & $\begin{array}{l}\text { State the process that will be used for selecting studies (such as two independent reviewers) through each phase of the review } \\
\text { (that is, screening, eligibility and inclusion in meta-analysis) }\end{array}$ & $\mathrm{X}$ \\
\hline $\begin{array}{l}\text { Data collection } \\
\text { process }\end{array}$ & $11 \mathrm{c}$ & $\begin{array}{l}\text { Describe planned method of extracting data from reports (such as piloting forms, done independently, in duplicate), any } \\
\text { processes for obtaining and confirming data from investigators }\end{array}$ & $\mathrm{X}$ \\
\hline Data items & 12 & $\begin{array}{l}\text { List and define all variables for which data will be sought (such as PICO items, funding sources), any pre-planned data } \\
\text { assumptions and simplifications }\end{array}$ & $\mathrm{X}$ \\
\hline $\begin{array}{l}\text { Outcomes and } \\
\text { prioritization }\end{array}$ & 13 & $\begin{array}{l}\text { List and define all outcomes for which data will be sought, including prioritization of main and additional outcomes, with } \\
\text { rationale }\end{array}$ & $\mathrm{X}$ \\
\hline $\begin{array}{l}\text { Risk of bias in } \\
\text { individual studies }\end{array}$ & 14 & $\begin{array}{l}\text { Describe anticipated methods for assessing risk of bias of individual studies, including whether this will be done at the outcom } \\
\text { or study level, or both; state how this information will be used in data synthesis }\end{array}$ & \\
\hline \multirow[t]{4}{*}{ Data synthesis } & $15 \mathrm{a}$ & Describe criteria under which study data will be quantitatively synthesised & $\mathrm{X}$ \\
\hline & $15 b$ & $\begin{array}{l}\text { If data are appropriate for quantitative synthesis, describe planned summary measures, methods of handling data and methods } \\
\text { of combining data from studies, including any planned exploration of consistency (such as } \mathrm{I}^{2}, \text { Kendall's } \tau \text { ) }\end{array}$ & \\
\hline & $15 \mathrm{c}$ & Describe any proposed additional analyses (such as sensitivity or subgroup analyses, meta-regression) & $\mathrm{X}$ \\
\hline & $15 \mathrm{~d}$ & If quantitative synthesis is not appropriate, describe the type of summary planned & $\mathrm{X}$ \\
\hline Meta-bias(es) & 16 & Specify any planned assessment of meta-bias(es) (such as publication bias across studies, selective reporting within studies) & \\
\hline $\begin{array}{l}\text { Confidence in } \\
\text { cumulative evidence }\end{array}$ & 17 & Describe how the strength of the body of evidence will be assessed (such as GRADE) & $\mathrm{X}$ \\
\hline
\end{tabular}

* It is strongly recommended that this checklist be read in conjunction with the PRISMA-P Explanation and Elaboration (cite when available) for important clarification on the items. Amendments to a review protocol should be tracked and dated. The copyright for PRISMA-P (including checklist) is held by the PRISMA-P Group and is distributed under a Creative Commons Attribution Licence 4.0.

From: Shamseer L, Moher D, Clarke M, Ghersi D, Liberati A, Petticrew M, Shekelle P, Stewart L, PRISMA-P Group. Preferred reporting items for systematic review and meta-analysis protocols (PRISMA-P) 2015: elaboration and explanation. BMJ. 2015 Jan 2;349(jan02 1):g7647. 